\title{
Community-Acquired Pneumonia in Children-An Update
}

\author{
MD KAMRUZZAMAN ${ }^{1}$, MIRZA MD. ZIAUL ISLAM ${ }^{2}$, PROBIR KUMAR SARKAR ${ }^{3}$
}

\begin{abstract}
Community-acquired pneumonia $(C A P)$ is a potentially serious infection in children and often results in hospitalization. CAP symptoms are nonspecific in younger infants, but cough and tachypnea are usually present in older children. The diagnosis can be based on the history and physical examination results in children with fever plus respiratory signs and symptoms. Chest radiography and rapid viral testing may be helpful when the diagnosis is unclear. The most likely etiology depends on the age of the child. Viral and Streptococcus pneumonia infections are most common in preschoolaged children, whereas Mycoplasmapneumoniaeis common in older children.Most children can be managed empirically with oral antibiotics as outpatients without specific laboratory investigations. The decision to treat with antibiotics is challenging, especially with the increasing prevalence of viral and bacterial coinfections. Those with severe infections or with persistent or worsening symptoms need more intensive investigations and may need admission to hospital. The choice and dosage of antibiotics should be based on the age of the patient, severity of the pneumonia and knowledge of local antimicrobial resistance patterns.
\end{abstract}

Keywords: Childhood, Community-acquired, Pneumonia, Diagnosis

\section{Background}

Community-acquired pneumonia is a common and potentially serious infection that afflicts children throughout the world; it is fundamentally different in children and in adults. The annual incidence of pneumonia in children younger than 5 years of age is 34 to 40 cases per 1000 in Europe and North America, higher than at any other time of life, except perhaps in adults older than 75 or 80 years of age. ${ }^{1}$ In the developing worldespecially, pneumonia is not only more common than it is in Europe and North America ${ }^{2}$ it is also more severe and is the largest killer of children ${ }^{3}$ Definitions of pneumonia vary widely. Some require only the presence of infiltrates on a chest radiograph, whereas others require only certain respiratory symptoms or signs.

1. Registrar, Pediatric Pulmonology, Department, Bangladesh Institute of child Health, Dhaka Shishu (Children) Hospital

2. Asstt. Professor, Pediatric Infectious Diseases and Community Pediatrics, Bangladesh Institute of Child Health, Dhaka Shishu (Children) Hospital

3. Associate Professor \& Head, Department of Pediatric Pulmonology, Bangladesh Institute of Child Health, Dhaka Shishu (Children) Hospital

Correspondence: Dr. Md. Kamruzzaman, Registrar, Pediatric Pulmonology Department, Bangladesh Institute of child Health, Dhaka Shishu (Children) Hospital, Email:drkamrul07 @gmail.com Cell: 01711123377

Received: 22 February 2017

Accepted: 13 March 2018
Definitions are a particular problem in the case of small infants, since pneumonia and bronchiolitis are both common in this age group, and the features of these two diseases often overlap. Many studies, particularly those in the developing world, use the term "acute lower respiratory tract illness" and make no attempt to differentiate pneumonia from bronchiolitis. ${ }^{2}$ For the purposes of this review, and particularly with respect to recommendations for treatment, pneumonia will be defined as the presence of fever, acute respiratory symptoms, or both, plus evidence of parenchymal infiltrates on chest radiography.

\section{Etiology}

A very large number of microorganisms can cause childhood pneumonia, and determining the cause of an individual case may be difficult. The lung itself is rarely sampled directly, and sputum representing lowerairway secretions can rarely be obtained from children. In addition, as is the case in adults, culture of secretions from the upper respiratory tract is not useful, since the normal flora includes the bacteria commonly responsible for pneumonia.

Multiple investigations of pediatric pneumonia during the 1960s and 1970s in North America and Europe emphasized the importance of infections with respiratory viruses (respiratory syncytial virus, 
influenzavirus, parainfluenza viruses, and adenovirus) in preschool children, Mycoplasma pneumoniae in schoolage children, and Chlamydia trachomatis in infants between two weeks and four months of age. More recently, C. pneumoniae has been found in school-age children with pneumonia, ${ }^{5-8}$ Similarly, the roles of cytomegalovirus, Ureaplasma urealyticum, Pneumocystis carinii, and more recently, rhinoviruses ${ }^{4}$ as causes of community-acquired pneumonia in otherwise healthy infants and children remain controversial.

The role of bacteria as a cause of severe pneumonia is best documented in lung-puncture studies, which have been conducted largely in the developing world. ${ }^{9-}$ 10 These have confirmed the importance of Streptococcus pneumoniae, Staphylococcus aureus, and Haemophilusinfluenzae, including non-typable strains, as causes of severe pneumonia.

There have been efforts over the past decade to define this role more clearly, largely through the measurement of bacterial antigens, nucleic acid (by means of the polymerasechain-reaction assay), antibodies, or immune complexes in blood or urine. ${ }^{4,11-16}$ The value of these tests is, however, questionable. Antigen tests lack specificity, ${ }^{38}$ and evidence of the sensitivity and specificity of bacterial antibody tests in children is either absent (in the case of non-typable $\mathrm{H}$. influenzae and Moraxella catarrhalis) or severely limited (S. pneumoniae). ${ }^{10}$ the apparent 35 percent reduction in the incidence of disease associated with the use of the recently licensed pneumococcal conjugate vaccine may provide the clearest estimate of the role of $S$. pneumoniae in causing childhood pneumonia in Europe and the United States. ${ }^{17-18}$

\section{Diagnosis}

Establishing a microbiologic diagnosis, despite its limitations, may be important in children with severe or complicated pneumonia or in those with unusual but treatable causes. As a practical matter, however, the cause of pneumonia can usually be surmised on the basis of clinical and epidemiologic data, findings on chest radiography, and a few laboratory tests such as a complete blood count, erythrocyte sedimentation rate, and levels of $\mathrm{C}$-reactive protein. Although it is difficult to determine the accuracy of such nonmicrobiologic diagnostic approaches because of the lack of an etiologic gold standard, there have been many attempts to correlate them with microbiologic causes.
Radiographic findings have less discriminatory value than does measurement of C-reactive protein, erythrocyte sedimentation rate, or the white-cell count and the differential count. alveolar (equivalent to a "lobar") infiltrate is an insensitive but reasonably specific indication of bacterial infection. typical bronchiolitis with scattered infiltrates to dense lobar pneumonia with a large pleural effusion the level of diagnostic certainty provided by radiologic findings is quite high. ${ }^{20-22}$

Non-microbiologic laboratory tests have also been widely used in an attempt to differentiate bacterial from nonbacterial pneumonia. However, they are not much better than chest radiographs. Several analyses show that the C-reactive protein level and the absolute neutrophil count are the most helpful. ${ }^{23-26}$

\section{Treatment}

Perhaps because of the many controversies that surround the etiologic process of community-acquired pneumonia in children, there have been few attempts to devise treatment guidelines in Europe or North America. In contrast, official recommendations regarding the treatment of pneumonia in adults have been published in Britain, Canada, and the United States. ${ }^{27-29}$ An ad hoc group of Canadian experts has published guidelines, ${ }^{30}$ and numerous recommendations address subgroups of patients with pneumonia, which are usually classified according to the cause. ${ }^{31-33}$ These guidelines, however, are designed for areas where pneumonia is a major killer, bacterial pneumonia is probably more common, access to drugs is limited, and the available diagnostic tools are few. ${ }^{34}$

Pneumonia during the first three weeks after birth is uncommon, but when it does occur it is often related to perinatally associated infections. Between three weeks and three months of age, two of the most important causes of pneumonia are macrolide-sensitive organisms: C. trachomatis is also one of the most common, and Bordetella pertussis is an infrequent cause of pneumonia. These pneumonias usually have an interstitial pattern of infiltrates, with cough as a prominent feature. In children who are older than five years of age, two other macrolide-sensitive organisms, M. pneumoniae and C. pneumoniae, cause pneumonia that, on chest radiograph, is often not distinguishable from bacterial pneumonia but that is characterized by cough, a low-grade fever, and sometimes wheezing. M. pneumoniae is the most common identified cause 
of pneumonia among children who are 5 to 15 years of age.

A child with pneumonia who is wheezing is likely to have a viral, M. pneumoniae, or $\mathrm{C}$. pneumoniae infection. ${ }^{35}$

Respiratory syncytial virus infection and influenza are uncommon outside their winter-spring epidemics. M. pneumoniaeepidemics are less predictable cases do occur in community-wide clusters during the winter.

Chest radiographs that show consolidative lobar infiltrates, particularly if either a large pleural effusion or any parenchymal necrosis is present, are indicative of a bacterial cause. When the whitecell count, differential count, and C-reactive protein level are very abnormal, they also have predictive value with respect to bacterial pneumonia and can corroborate a diagnosis ${ }^{36}$

In infants who are 3 weeks to 3 months of age and in those who are 5 to 15 years of age, a macrolide antibiotic is the most reasonable first, second- or thirdgeneration cephalosporin should be used for children with sepsis, except forinfants, who should receive bothampicillin and gentamicin, as well as a thirdgeneration cephalosporin in severe cases. In areas where methicillin-resistant strains of $\mathrm{S}$. aureus have appeared,vancomycin should then be added to the regimen. If the condition of school-age children does not improve with the use of cephalosporin or if the findings on the chest radiograph or the clinical findings are ambiguous, a macrolide should be added ${ }^{37-39}$,

The emergence of strains of $\mathrm{S}$. pneumoniae that are not susceptible to penicillin a second-generation cephalosporin (cefuroxime) or a third-generation cephalosporin (cefotaxime or ceftriaxone) is somewhat more effective.high dose of amoxicillin (80 to $100 \mathrm{mg}$ per kilogram of body weight per day) is the preferred treatment for pneumonia in outpatients. Vancomycin is rarely needed to treat pneumococcal pneumonia, even severe cases. ${ }^{40-41}$

Use of the recently licensed pneumococcal conjugate vaccine appears likely to prevent the majority of cases of pneumococcal pneumonia,vaccinated persons that pneumococcal serotypes not represented in the vaccine are replacing the serotypes covered by the vaccine and are causing otitis media. ${ }^{42}$ The World Health Organization's approach to the treatment of pneumonia, despite its success, may well aggravate the problem of antibiotic resistance in communities that have the highest rates of death from pneumonia. ${ }^{43}$

\section{Conclusions}

Pneumonia in children has been relatively refractory to efforts and to reduce its incidence and severity. The use of treatment algorithms in the developing world has led to lower mortality rates. There is still room for improvements in the diagnosis of pneumonia and in the elucidation of its cause in individual cases. Finally, regional consensus guidelines for management and antimicrobial treatment should be developed for appropriate management of community acquired pneumonia.

\section{References}

1. Jokinen $\mathrm{C}$, Heiskanen $\mathrm{L}$, Juvonen $\mathrm{H}$, et al. Incidence of communityacquired pneumonia in the population of four municipalities in eastern Finland. Am J Epidemiol 1993;137:977-88.

2. Selwyn BJ. The epidemiology of acute respiratory tract infection in young children: comparison of findings from several developing countries. Rev Infect Dis 1990;12:Suppl 8:S870-S888.

3. Baqui AH, Black RE, Arifeen SE, Hill K, Mitra $\mathrm{SN}$, al Sabir A. Causes of childhood deaths in Bangladesh: results of a nationwide verbal autopsy study. Bull World Health Organ 1998;76:161-71.

4. Juven T, Mertsola J, Waris M, et al. Etiology of community-acquired pneumonia in 254 hospitalized children. Pediatr Infect Dis J 2000;19:293- 8 .

5. Grayston JT, Campbell LA, Kuo CC, et al. A new respiratory tract pathogen: Chlamydia pneumoniae strain TWAR. J Infect Dis 1990;161: 618-25.

6. Hammerschlag MR. Atypical pneumonias in children.AdvPediatr Infect Dis 1995;10:1-39.

7. Heiskanen-Kosma T, Korppi M, Laurila A, Jokinen C, Kleemola M, Saikku P. Chlamydia pneumoniae is an important cause of communityacquired pneumonia in school-aged children: serological results of a prospective, population-based study. Scand J Infect Dis 1999;31:255-9.

8. Wubbel L, Muniz L, Ahmed A, et al. Etiology and treatment of community-acquired pneumonia in ambulatory children. Pediatr Infect Dis J 1999;18:98-104. 
9. Falade AG, Mulholland EK, Adegbola RA, Greenwood BM. Bacterial isolates from blood and lung aspirate cultures in Gambian children with lobar pneumonia. Ann Trop Paediatr 1997;17:315-9.

10. Forgie IM, O'Neill KP, Lloyd-Evans $\mathrm{N}$, et al. Etiology of acute lower respiratory tract infections in Gambian children. II. Acute lower respiratory tract infection in children ages one to nine years presenting at the hospital. Pediatr Infect Dis J 1991;10:42-7.

11. Heiskanen-Kosma T, Korppi M, Jokinen C, et al. Etiology of childhood pneumonia: serologic results of a prospective, population-based study. Pediatr Infect Dis J 1998;17:986-91.

12. Korppi M, Heiskanen-Kosma T, Jalonen E, et al. Aetiology of community-acquired pneumonia in children treated in hospital. Eur $\mathrm{J}$ Pediatr1993;152:24-30.

13. Lankinen KS, Ruutu $P$, Nohynek $H$, Lucero $M$, Paton JC, Leinonen M. Pneumococcal pneumonia diagnosis by demonstration of pneumolysin antibodies in precipitated immune complexes: a study in 350 Philippine children with acute lower respiratory infection. Scand $J$ Infect Dis 1999; 31:155-61.

14. Nohynek H, Eskola J, Laine E, et al. The causes of hospital-treated acute lower respiratory tractinfection in children. Am JDis Child 1991; 145:618-22.

15. Toikka P, Nikkari S, Ruuskanen O, Leinonen M, Mertsola J. Pneumolysin PCR-based diagnosis of invasive pneumococcal infection in children. $J$ ClinMicrobiol 1999;37:633-7.

16. Gendrel D, Raymond J, Moulin F, et al. Etiology and response to antibiotic therapy of communityacquired pneumonia in French children. Eur J ClinMicrobiol Infect Dis 1997;16:388-91.

17. Black S, Shinefield H, Fireman B, et al. Efficacy, safety and immunogenicity of heptavalent pneumococcal conjugate vaccine in children. Pediatr Infect Dis J 2000;19:187-95.

18. Shinefield HR, Black S. Efficacy of pneumococcal conjugate vaccines in large scale field trials. Pediatr Infect Dis J 2000;19:394-7.

19. Forgie IM, O'Neill KP, Lloyd-Evans $\mathrm{N}$, et al. Etiology of acute lower respiratory tract infections in Gambian children. I. Acute lower respiratory tract infections in infants presenting at the hospital. Pediatr Infect Dis J 1991;10:33-41.

20. Korppi M, Kiekara O, Heiskanen-Kosma T, Soimakallio S. Comparison of radiological findings and microbial aetiology of childhood pneumonia. ActaPaediatr1993;82:360-3.

21. Markowitz RI, Ruchelli E. Pneumonia in infants and children: radiological-pathological correlation. SeminRoentgenol1998;33:151-62.

22. Toikka P, Virkki R, Mertsola J, Ashorn P, Eskola J, Ruuskanen O. Bacteremic pneumococcal pneumonia in children. Clin Infect Dis 1999;29: 568-72.

23. Nohynek H, Valkeila E, Leinonen M, Eskola J. Erythrocyte sedimentation rate, white blood cell count and serum C-reactive protein in assessing etiologic diagnosis of acute lower respiratory infections in children. Pediatr Infect Dis J 1995;14:484-90.

24. Korppi M, Kroger L. C-reactive protein in viral and bacterial respiratory infection in children. Scand J Infect Dis 1993;25:207-13.

25. Korppi M, Heiskanen-Kosma T, Leinonen M. White blood cells, C-reactive protein and erythrocyte sedimentation rate in pneumococcal pneumonia in children. EurRespirJ 1997;10: 1125-9.

26. Korppi M, Kroger L, Laitinen M. White blood cell and differential counts in acute respiratory viral and bacterial infections in children. Scand J Infect Dis 1993;25:435-40.

27. Guidelines for the management of communityacquired pneumonia in adults admitted to hospital. Br J Hosp Med 1993;49:346-50.

28. Niederman MS, Bass JB Jr, Campbell GD, et al. Guidelines for the initial management of adults with community-acquired pneumonia: diagnosis, assessment of severity, and initial antimicrobial therapy. Am Rev Respir Dis 1993;148:1418-26.

29. Bartlett JG, Dowell SF, Mandell LA, File TM Jr, Musher DM, Fine MJ. Practice guidelines for the management of community-acquired pneumonia in adults. Clin Infect Dis 2000;31:347-82.

30. Jadavji T, Law B, Lebel MH, Kennedy WA, Gold $R$, Wang EE. A practical guide for the 
diagnosisand treatment of pediatric pneumonia. CMAJ 1997;156:S703-S711.

31. Schutze GE, Jacobs RF. Management of community-acquired bacterial pneumonia in hospitalized children. Pediatr Infect Dis J 1992;11:160-4.

32. Therapy for children with invasive pneumococcal infections. Pediatrics 1997;99:289-99.

33. Pickering LK, ed. 2000 Red book: report of the Committee on Infectious Diseases. 25th ed. Elk Grove Village, III.: American Academy of Pediatrics, 2000.

34. Shann F. The management of pneumonia in children in developing countries. Clin Infect Dis 1995;21:Suppl 3:S218-S225.

35. Davies HD, Matlow A, Petric M, Glazier R, Wang EEL. Prospective comparative study of viral, bacterial and atypical organisms identified in pneumonia and bronchiolitis in hospitalized Canadian infants. Pediatr Infect Dis $\mathrm{J}$ 1996;15:371-5.

36. Bachur R, Perry H, Harper MB. Occult pneumonias: empiric chest radiographs in febrile children with leukocytosis. Ann Emerg Med 1999;33: 166-73.

37. Block S, Hedrick J, Hammerschlag MR, Cassell $\mathrm{GH}$, Craft JC. Mycoplasma pneumoniae and Chlamydia pneumoniae in pediatric community acquired pneumonia: comparative efficacy and safety of clarithromycin vs. erythromycin ethylsuccinate. Pediatr Infect Dis J 1995;14: 471-7.

38. Hardie WD, Roberts NE, Reising SF, Christie CD. Complicated parapneumonic effusions in children caused by penicillin-nonsusceptible Streptococcus pneumoniae. Pediatrics 1998;101:388-92.

39. Frank AL, Marcinak JF, Mangat PD, Schreckenberger PC. Increase in communityacquired methicillin-resistant Staphylococcus aureus in children. Clin Infect Dis 1999;29: 935-6.

40. Pallares R, Liñares J, Vadillo M, et al. Resistance to penicillin and cephalosporin and mortality from severe pneumococcal pneumonia in Barcelona, Spain. N Engl J Med 1995;333:474-80.

41. Friedland IR. Comparison of the response to antimicrobial therapy of penicillin-resistant and penicillin-susceptible pneumococcal disease. Pediatr Infect Dis J 1995;14:885-90.

42. Choi E-H, Lee H-J. Clinical outcome of invasive infections by penicillin-resistant Streptococcuspneumoniae in Korean children. ClinInfect Dis 1998;26:1346-54.

43. Eskola J, Kilpi T, Palmu A, et al. Efficacy of a pneumococcal conjugate vaccine against acute otitis media. N Engl J Med 2001;344:403-9. 83. Sazawal S, Black RE. Meta-analysis of intervention trials on casemanagement ofpneumonia in community settings. Lancet 1992;340:528- 33. 